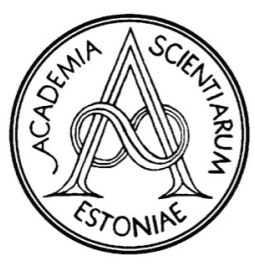

Proceedings of the Estonian Academy of Sciences, $2021,70,2,163-171$

https://doi.org/10.3176/proc.2021.2.04

Available online at www.eap.ee/proceedings

COATING AND

TRIBOLOGY

\title{
TiAlN coatings tribology for textile machinery parts
}

\author{
Abrar Hussain*, Vitali Podgursky, Dmitri Goljandin and Maksim Antonov \\ Department of Mechanical and Industrial Engineering, Tallinn University of Technology, Ehitajate tee 5, 19086 Tallinn, Estonia
}

Received 16 November 2020, accepted 4 January 2021, available online 13 April 2021

(C) 2021 Authors. This is an Open Access article distributed under the terms and conditions of the Creative Commons AttributionNonCommercial 4.0 International License (http://creativecommons.org/licenses/by-nc/4.0/).

\begin{abstract}
Rough, damaged, and distorted post-consumer natural and synthetic polymers cause wear and damage to textile machinery parts, presenting a major obstacle to the quality of recycled products. In this research, TiAlN coatings were used to measure the coefficient of friction (COF) for tribological properties. The scanning electron microscope (SEM) studies of cotton textiles revealed surface damage, distortions, and loose fibres produced on the fabric surface. SEM morphology of TiAlN coatings was found smooth and uniform. Additionally, Contour GT-K 3D optical microscope and mechanical profilometer (Mahr Perthometer) were used for coating surface analysis. The average coating surface roughness parameters were $\operatorname{Rmax}(0.30 \mu \mathrm{m}), \operatorname{Rz}(0.26 \mu \mathrm{m})$, and $\operatorname{Rp}(0.17 \mu \mathrm{m})$. The microhardness value was $35 \mathrm{GPa}$ on the HV scale. The lower surface roughness and higher hardness values are an indication of reasonable quality and performance of textile fabrics during recycling. The dynamic COF values were obtained from 0.47 to 0.30 in warp and from 0.35 to 0.23 in weft directions. Higher COF values occurred in the warp direction due to lower thread densities, rough surface, preferred fibre orientation, randomly oriented fibres, and a plain-woven structure. Based on the COF values, permanent deformation, and morphology evaluations, TiAlN coatings could be used optimistically for surface modification of shredding, cutting, and textile machinery parts. The TiAlN coatings applications in industries could also enhance the quality and performance of recycled textile products.
\end{abstract}

Key words: fabric tribology, coatings, wear, fabric friction, textile fabrics, textile machinery.

\section{INTRODUCTION}

Wear, erosion, chemical corrosion, and fatigue have caused operational problems in textile manufacturing and recycling industries $[1,2]$. Shredding, spinning, weaving, and finishing are the main operational manufacturing processes [3]. These processes reflect the quality and performance of cotton fabric products [4]. Additionally, the mechanical components, tools, and machinery parts require smooth surface, high wear resistance, and an optimized coefficient of friction (COF) for this kind of manufacturing [5-8]. Such growing requirements demand innovations and development of new coatings [9].

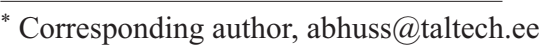

Usually, diamond-like carbon (DLC) coatings, nitrogenbased coatings (TiAlN/TiCN/TiN), carbon-based coatings ( $\mathrm{SiC} / \mathrm{WC} / \mathrm{VC})$, thin-film oxide $\left(\mathrm{Al}_{2} \mathrm{O}_{3} / \mathrm{Cr}_{2} \mathrm{O}_{3} / \mathrm{ZrO}_{2}\right)$ coatings, and boride coatings are introduced for investigations of tribological properties [10-12]. The development and demand for new materials with controlled properties are a growing need for the current age [13]. These materials allow better wear and corrosion resistance to textile machinery components and tools [14]. The application of the above-mentioned materials as a coating on textile machinery parts enhances both the service life of the parts and the quality of textile products [15]. Metal matrix ceramics composites (MMCs) are also important materials for the components of textile and manufacturing machinery. The coatings of these materials improve the 
performance of textile machinery parts and the quality of textile products [16-18], minimizing also the replacement sequence of machinery. Furthermore, the suitable selection of matrix materials for machinery parts and coatings can modify wear properties for required applications [19].

Generally, two principal techniques are employed for the estimation of fabric friction [20-22]. In the first technique, an object with the mass 'm' slides on a polymer fabric to determine both the dynamic and static friction of the fabric:

$$
\mu_{\text {dynamic }}=\frac{F}{m g} \text {, }
$$

where "F" denotes the applied force, " $\mu_{\text {dynamic }}$ is the friction constant, "g" represents the gravitational acceleration constant, " $\mathrm{m}$ " is the mass of the sliding body.

In the second technique, an inclined plane is used to calculate the friction constant. The same parameters are applied and the new formulation is described as

$$
\mu_{\text {static }}=\tan \theta \text {. }
$$

Here " $\mu_{\text {static }}$ " is the friction constant and " $\theta$ " denotes the inclined angle.

In this research, TiAlN thin film coatings were evaluated for tribological properties to enhance the quality and performance of post-consumer polymeric materials. A new innovative method was developed to determine the COF of post-consumer natural and artificial polymers. The optimization was performed by using the variations in the COF related to distance, normal force, and sliding speeds. TiAlN coated steel balls were employed to investigate the coefficient of friction (COF) against cotton textiles. The wear of cotton fabric was examined by means of the CETR tribometer, by varying normal load, distance, and speed from $0.5 \mathrm{~N}$ to $9 \mathrm{~N}$, from $0 \mathrm{~m}$ to $80 \mathrm{~m}$, and from $1 \mathrm{~mm} / \mathrm{s}$ to $10 \mathrm{~mm} / \mathrm{s}$, respectively. The surface morphologies of cotton textile and TiAlN coated steel balls were characterized by using a scanning electron microscope (SEM). Optical and mechanical profilometers were used for surface evaluations of the TiAlN coated balls and a Vickers micro- hardness tester was utilized for the estimation of coating surface hardness.

\section{EXPERIMENTAL}

\subsection{Materials}

The post-consumer cotton textile was C2 (fabric code) plain-woven cotton. The yarn density was 36 threads/cm in the warp direction and 18 threads/cm in the weft direction. The subjective assessment [23] of different parameters is described in Table 1.

The cotton fabric was cut into small rectangular strips of the size $5 \mathrm{~cm} \times 2.5 \mathrm{~cm}$ for COF evaluations. Using epoxy adhesive, the strips were mounted on mild steel blocks with the dimensions of $25 \mathrm{~mm} \times 10 \mathrm{~mm} \times 50 \mathrm{~mm}$. The adhesive was smeared directly on metal blocks and permitted to cure for 20 seconds. The curing time avoids the penetration of epoxy into porous fabrics. The twist factor was kept constant for post-consumer cotton fabric.

TiAlN coated steel balls were employed for the investigation of surface tribological properties. Coatings were deposited on steel balls in the arc plating PVD-unit PLATIT- $\pi 80$ using the lateral rotating ARC-Cathodes (LARC) technology. TiAlN consists of $50 \%$ of Al content in the (Ti1-xAlx) N coating. The deposition temperature was kept at $450^{\circ} \mathrm{C}$. Three clean HSS (HSS X82WMoV65) substrates were used for the deposition of each coating. The coating thickness was $2.3 \mu \mathrm{m}$. Additionally, morphologies of cotton fabric surface and TiAlN coated steel balls were determined by means of a scanning electron microscope (SEM). Microvicker and surface roughness tests were performed to measure the hardness and surface roughness of the TiAlN coated steel balls.

\subsection{Innovative method}

The coefficient of friction was calculated by using a surface tribometer as shown in Fig. 1. To carry out the experiment, the generation of sliding and reciprocation

Table 1. Subjective assessment of post-consumer cotton textile

\begin{tabular}{l|c|c|c|c|c}
\hline \multicolumn{1}{c|}{ Physical property } & Unit & Value & Physical property & Unit & Value \\
\hline Woven weft & - & Plain & $\begin{array}{c}\text { Thread diameter in weft } \\
\text { direction }\end{array}$ & $\mathrm{mm}$ & 0.345 \\
Woven warp & - & Plain & $\begin{array}{c}\text { Thread diameter in warp } \\
\text { direction }\end{array}$ & $\mathrm{mm}$ & 0.345 \\
Weight & $\mathrm{g} / \mathrm{m}^{2}$ & 237 & Twist value & $\mathrm{T} / \mathrm{m}$ & 800 \\
Warp linear density & $\mathrm{cm}^{-1}$ & 29 & Thickness & $\mathrm{mm}$ & 0.45 \\
Weft linear density & $\mathrm{cm}^{-1}$ & 29 & - & -
\end{tabular}




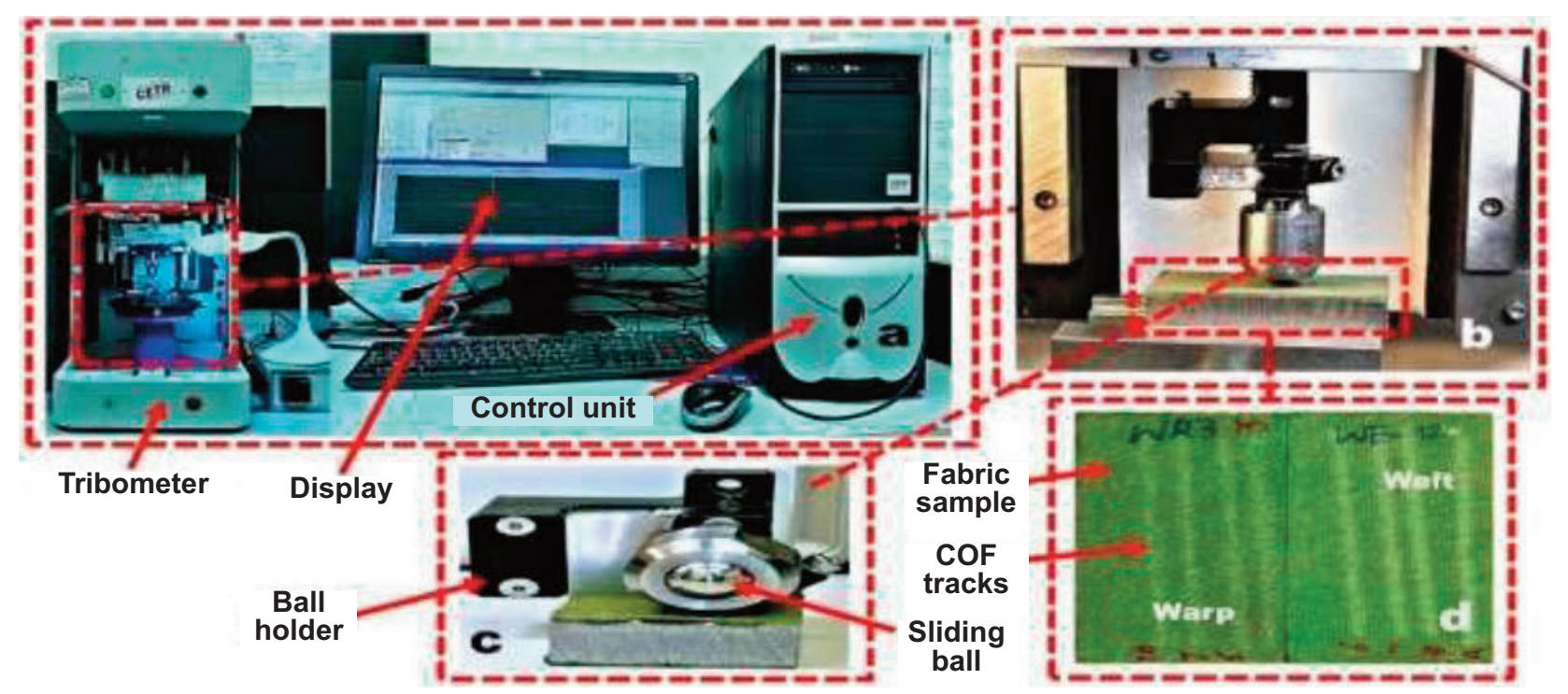

Fig. 1. COF setup: (a) tribometer equipment, (b) experiment demonstration, (c) ball slider and (d) fabric sample.

motions was needed. The experimental setup is demonstrated in Fig. 1a. The tribometer incorporates two parts, as seen in Fig. 1b. The upper part includes a ball slider and the lower part has circular support utilized for sample clamping. The force of the slider (Fig. 1c) is $0-200 \mathrm{~N}$, and the speed range is $0.5-15 \mathrm{~mm} / \mathrm{s}$. The lower circular stand with $300 \mathrm{~mm}$ diameter can move vertically and horizontally. The cotton samples (Fig. 1d) to be tested were clamped on the circular stand on two sides to avoid wrinkling or buckling during testing.

Tribological properties were investigated in weft and warp directions. Ten samples were utilized to measure the friction between the ball and the fabric in the weft direction and in the warp direction. The wear for $40 \mathrm{~mm}$ fabric was tested by using variations in normal load and speed from $0.5 \mathrm{~N}$ to $9 \mathrm{~N}$ and from $1 \mathrm{~mm} / \mathrm{s}$ to $10 \mathrm{~mm} / \mathrm{s}$, respectively. The duration of the test varied from $4 \mathrm{~s}$ to $40 \mathrm{~s}$. The TiAlN coated steel balls were employed as counter bodies. Moreover, the wear of $80 \mathrm{~m}$ fabric cotton was also taken into consideration for the optimization of industrial applications.

\section{RESULTS AND DISCUSSION}

Initially, the nature of pristine post-consumer cotton fabric was probed by means of the SEM. Figures $2 \mathrm{a}, 2 \mathrm{~b}$ and $2 \mathrm{c}, 2 \mathrm{~d}$ display the SEM images of cotton fabric in weft and warp directions, respectively. The fibres are arranged in vertical and parallel directions with twist values $(800 \mathrm{~T} / \mathrm{m})$. Under low magnification, SEM images $2 \mathrm{a}$ (X 50) and 2c (X 50) show that the pristine cotton fabric had round fibres. Moreover, the cotton fabrics had also loose fibres that drifted over the yarn surface in three dimensions. Highmagnification SEM images $2 \mathrm{~b}(\mathrm{X} 5.00 \mathrm{~K})$ and $2 \mathrm{~d}$ (X 5.00 K) give evidence of the damage and distortion of surface fibres. The surface damage, distortions, and loose fibres on the yarn surface were produced due to mechanical and chemical treatments during service life [24]. Hearle et al. have provided a detailed reference collection of more than 1500 SEM images. The distortion and damage incurred on fibres creates buckling and tangling effects in fabric and machinery parts [25]. The aforesaid collection discloses information about surface analysis, fibre ends, and crosssection areas. Based on the collection, Hearle et al. proved that newly manufactured woven textile products had a smooth surface and fibres did not drift over yarns. The SEM images taken of TiAlN coated balls after tribology testing are shown in Figs $3 \mathrm{a}$ and $3 \mathrm{~b}$. The surface was found quite smooth with a homogeneous distribution of coatings. The surface roughness measurements were also used for the evaluations of surface smoothness [26]. However, some scratches and impurities can be detected. As illustrated in Table 2, the surface roughness parameters of the TiAlN coated steel balls measured by Contour GT-K 3D optical microscope $-\operatorname{Rmax}(0.40 \mu \mathrm{m}), \mathrm{Rz}(0.36 \mu \mathrm{m})$, and $\operatorname{Rp}(0.28 \mu \mathrm{m})$ - were found slightly different from the surface roughness parameters measured by mechanical profilometer (Mahr Perthometer) - Rmax $(0.30 \mu \mathrm{m})$, Rz $(0.26 \mu \mathrm{m})$, and $\mathrm{Rp}(0.17 \mu \mathrm{m})$ [27].

At first, one-directional sliding motion was used to study the COF. The general graphs of COF values in reference to sliding time are represented in Figs $4 a-4 d$. The force, speed, and wear distance were altered in studying the COF. Graphs 4a, 4b, 4c, and 4d show the cotton fabric response to force and speed in warp and weft 

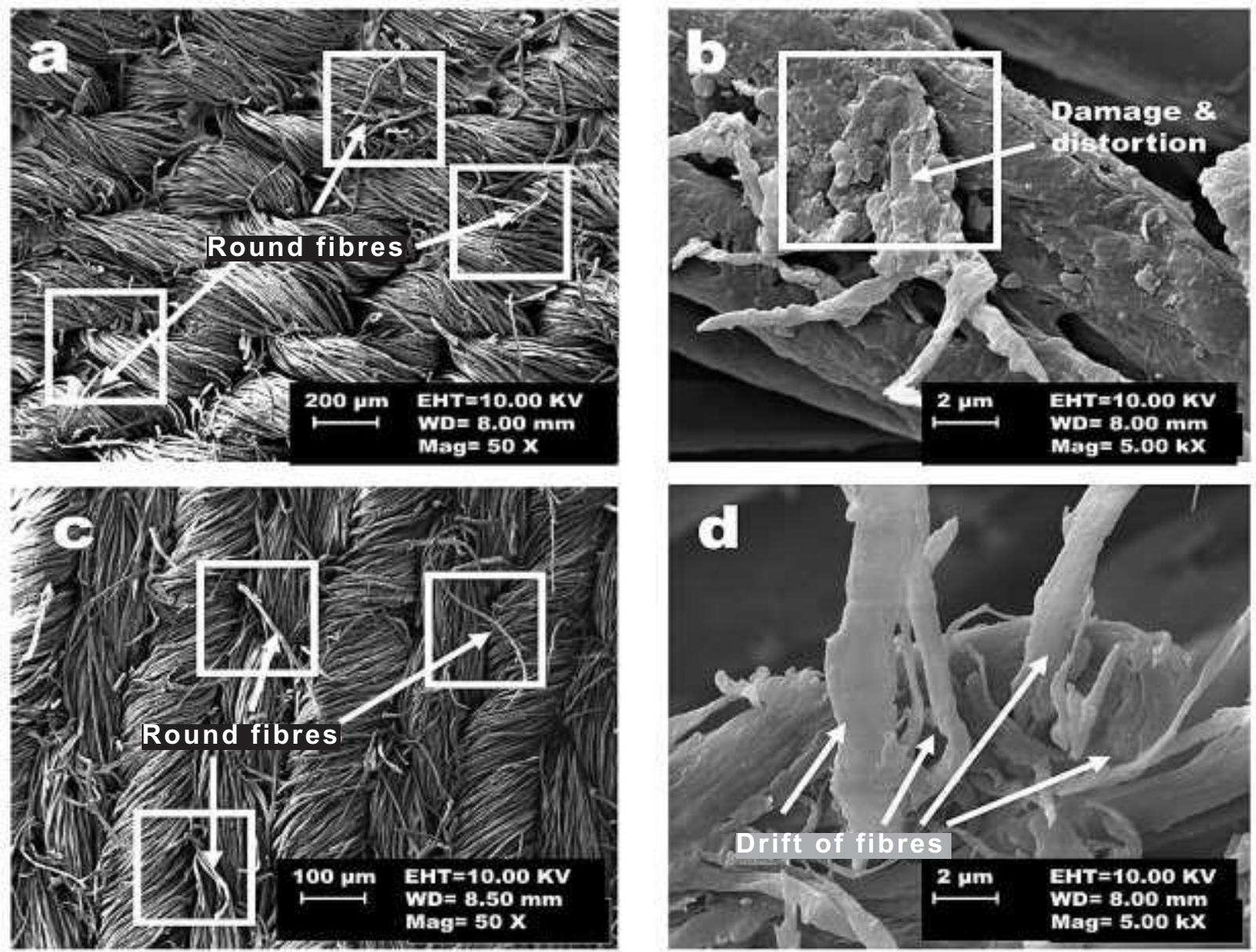

Fig. 2. SEM images: (a) (X 50) weft round fibres, (b) (X 5.00 K) weft rough and distorted fibres, (c) (X 50) warp round fibres, (d) $(\mathrm{X} 5.00 \mathrm{~K})$ warp rough and distorted fibres.
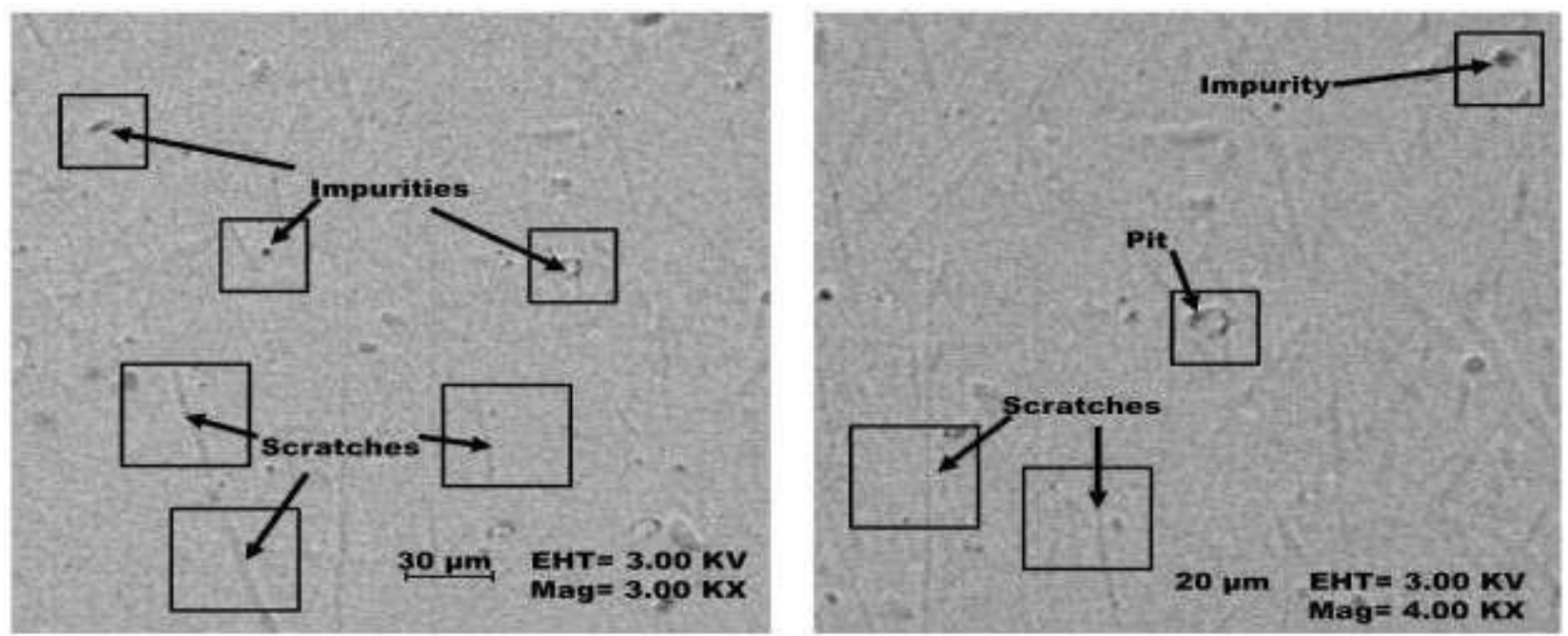

Fig. 3. SEM images of TiAlN coated steel balls: (a) at (X $3.00 \mathrm{~K})$ and (b) at (X $4.00 \mathrm{~K}$ ) magnifications. 
Table 2. Average surface roughness and microhardness of TiAlN coated steel balls for tribological performance

\begin{tabular}{l|c|c|c|c|c|c}
\hline \multirow{2}{*}{ Device } & \multicolumn{2}{c|}{$\begin{array}{c}\text { Surface roughness parameters } \\
(\mu \mathrm{m})\end{array}$} & $\begin{array}{c}\text { Nano } \\
\text { hardness } \\
(\mathrm{GPa})\end{array}$ & Coating colour & Applications \\
\cline { 2 - 7 } & $\mathrm{Rmax}$ & $\mathrm{Rz}$ & $\mathrm{Rp}$ & $\mathrm{HV}$ & Violet blue & Cutting, recycling \\
\hline Optical & 0.4 & 0.36 & 0.28 & - & - & - \\
Mechanical & 0.30 & 0.26 & 0.17 & - & - & - \\
Nano Indenter & - & - & - & 35 & -
\end{tabular}

directions, respectively. The results show that at a constant speed of $1 \mathrm{~mm} / \mathrm{s}$, in the case of TiAlN coated balls, for the value of force increasing from $0.5 \mathrm{~N}$ to $9 \mathrm{~N}$ the $\mathrm{COF}$ value decreases from 0.47 to 0.30 in the warp direction and from 0.35 to 0.23 in the weft direction. The COF variations are indicated in Table 3.

The speed variations for coated balls at a constant load of $8 \mathrm{~N}$ reduce the COF up to 0.03 in the warp direction, and almost no change occurs in the weft direction, see Figs $4 \mathrm{e}$ and $4 \mathrm{f}$. Figures $5 \mathrm{a}$ and $5 \mathrm{~b}$ show the deformation and wear of fibres after the sliding tests at the normal load of $8 \mathrm{~N}$ and the speed of $3 \mathrm{~mm} / \mathrm{s}$ and $10 \mathrm{~mm} / \mathrm{s}$ in weft and warp directions, respectively. The COF variations are demonstrated in Table 4.

Various assessments, observations, and evaluations can be made on the basis of friction data. The COF was detected higher in perpendicular orientation (warp direction) than in parallel orientation (weft direction). This points out the characteristic that may be distinctive to the investigated cotton fabric [20,28,29]. Normally, such behaviour is not observed for other natural and artificial textile fabrics. The fact that the COF is greater in the warp direction than in the weft direction is likely due to the fabric structure. The fabric and SEM images are shown in Figs 2a, 2c and 5a, 5b, respectively. At higher magnification, the yarns aligned from left to right in parallel (weft) orientation serve as a reference track for the sliding metallic ball. For illustration, see the SEM images in Figs 1d, 2a and 2b. During sliding both in warp and weft directions more encounters are noted due to rough surface and randomly oriented fibres.

The sliding motion was altered to reciprocation motion. The sliding distance was increased to study the $\mathrm{COF}$ and wear in more detail. At a load of $3 \mathrm{~N}$ and a speed of $1 \mathrm{~mm} / \mathrm{s}$, for $80 \mathrm{~m}$ of sliding distance the TiAlN coatings heavily deformed and fractured the fabric surface. At first, the COF varied significantly with wear distance in warp and weft directions. After 40 metres of wear distance, the $\mathrm{COF}$ values became constant for both directions. The results are shown in Figs $6 \mathrm{a}-6 \mathrm{~d}$. The results prove that the $\mathrm{COF}$ is of great importance for cotton industry practices.
Table 3. COF results of TiAlN coated steel balls for force variations in weft and warp directions

\begin{tabular}{l|l|c|c}
\hline $\begin{array}{l}\text { Sample } \\
\text { number }\end{array}$ & $\begin{array}{c}\text { Force } \\
(\mathrm{N})\end{array}$ & $\begin{array}{c}\text { COF in warp } \\
\text { direction }\end{array}$ & $\begin{array}{c}\text { COF in weft } \\
\text { direction }\end{array}$ \\
\hline 1 & 0.5 & 0.47 & 0.35 \\
2 & 1 & 0.38 & 0.31 \\
3 & 2 & 0.34 & 0.30 \\
4 & 3 & 0.34 & 0.28 \\
5 & 4 & 0.35 & 0.29 \\
6 & 5 & 0.30 & 0.25 \\
7 & 6 & 0.37 & 0.25 \\
8 & 7 & 0.34 & 0.24 \\
9 & 8 & 0.30 & 0.22 \\
10 & 9 & 0.30 & 0.23
\end{tabular}

Table 4. COF results of TiAlN coated steel balls for speed variations in weft and warp directions

\begin{tabular}{l|c|c|c}
\hline $\begin{array}{l}\text { Sample } \\
\text { number }\end{array}$ & $\begin{array}{c}\text { Speed } \\
(\mathrm{mm} / \mathrm{s})\end{array}$ & $\begin{array}{c}\text { COF in warp } \\
\text { direction }\end{array}$ & $\begin{array}{c}\text { COF in weft } \\
\text { direction }\end{array}$ \\
\hline 1 & 1 & 0.30 & 0.25 \\
2 & 3 & 0.27 & 0.25 \\
3 & 5 & 0.27 & 0.27 \\
4 & 7 & 0.25 & 0.26 \\
5 & 10 & 0.25 & 0.26
\end{tabular}

Kothari et al. studied the cutting of textile materials and proved that cutting of textile could be expressed in terms of cutting resistance index (CRI) [30]. The TiAlN coatings provide low cutting resistance and better grip between the tip of the cutting tool and the fabric surface during cutting $[31,32]$. The coatings with COF values lower than 0.2 may be considered efficient for high-quality manufactured fabric products. The quality and performance of recycled textile fabrics rely on initial shredding and cutting 

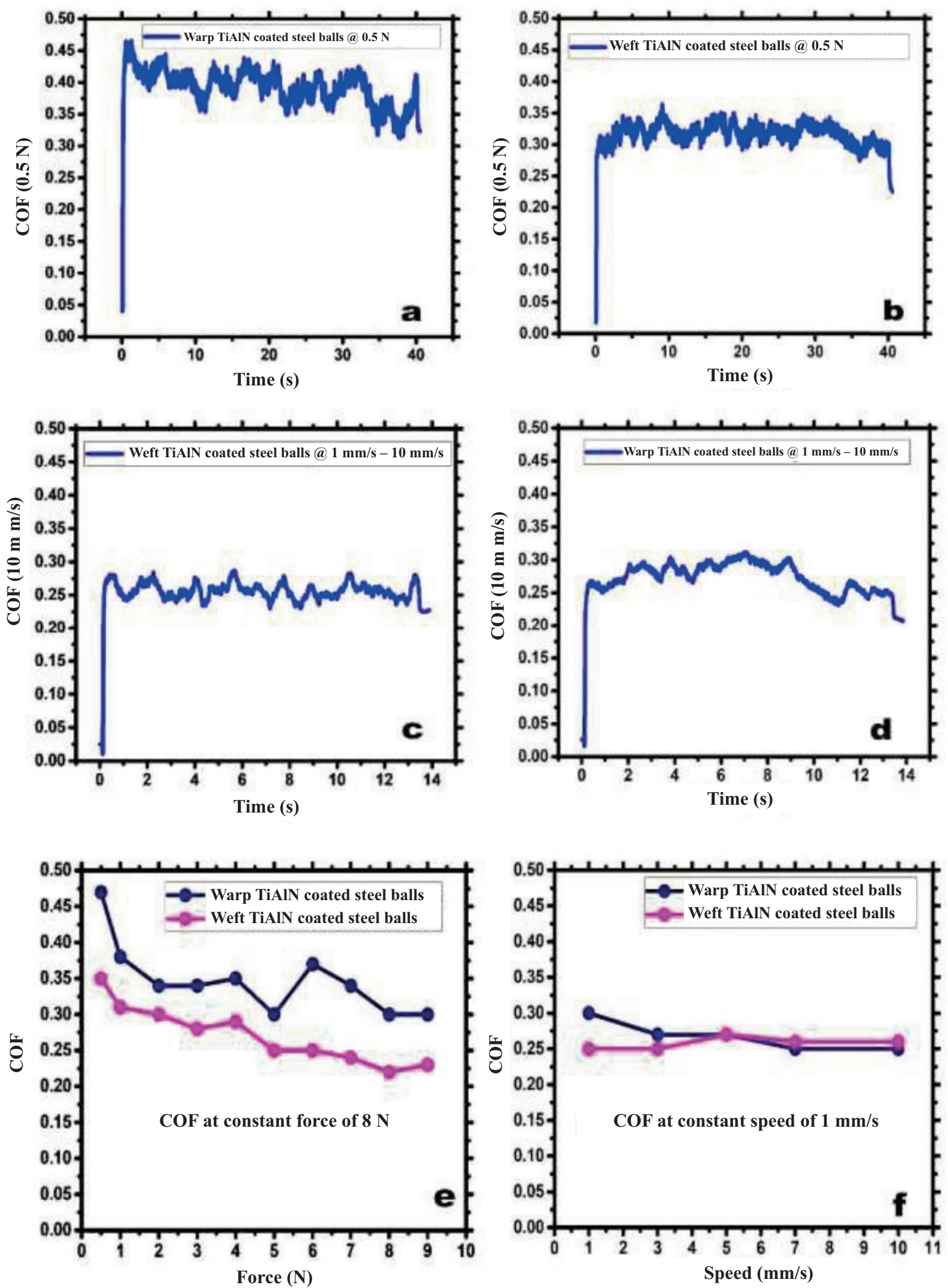

Fig. 4. TiAlN COF general demonstrations: (a) warp direction, (b) weft direction, (c) weft speed variations, (d) warp speed variations, (e) force comparison and (f) speed comparison. 

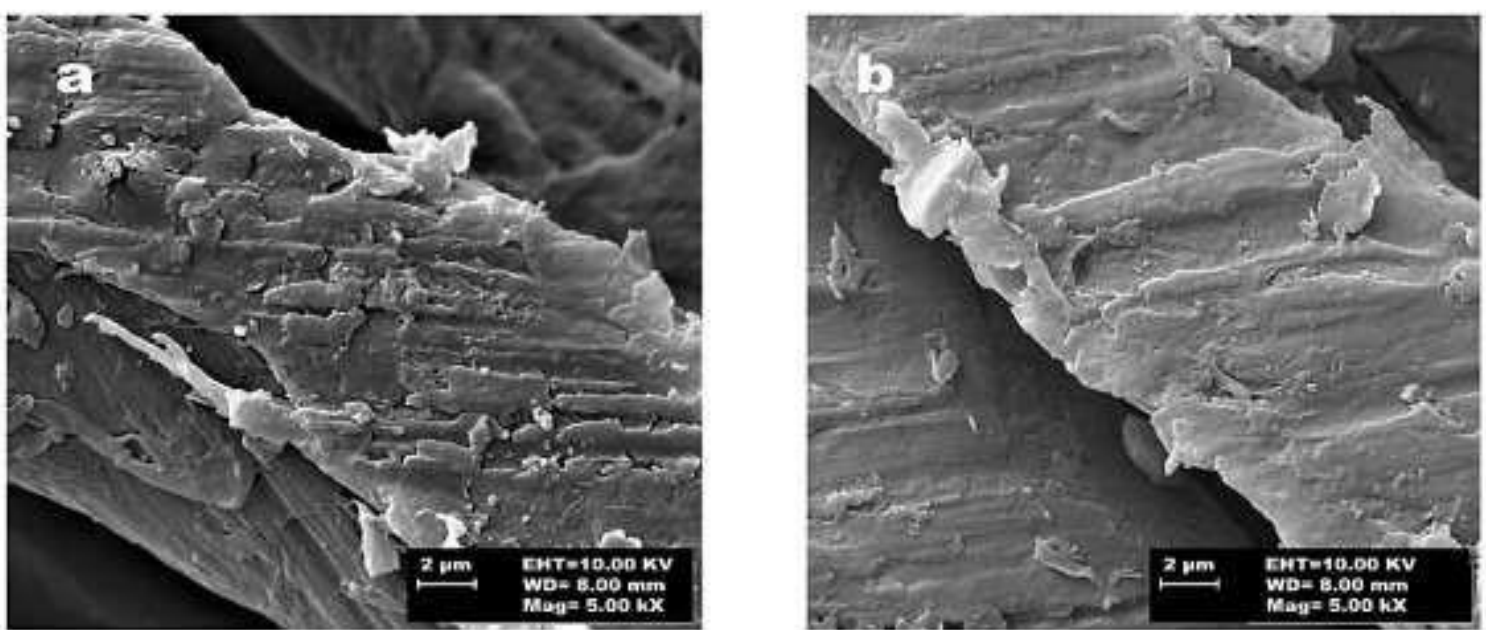

Fig. 5. Fibre deformation and wear in (a) weft and (b) warp directions.
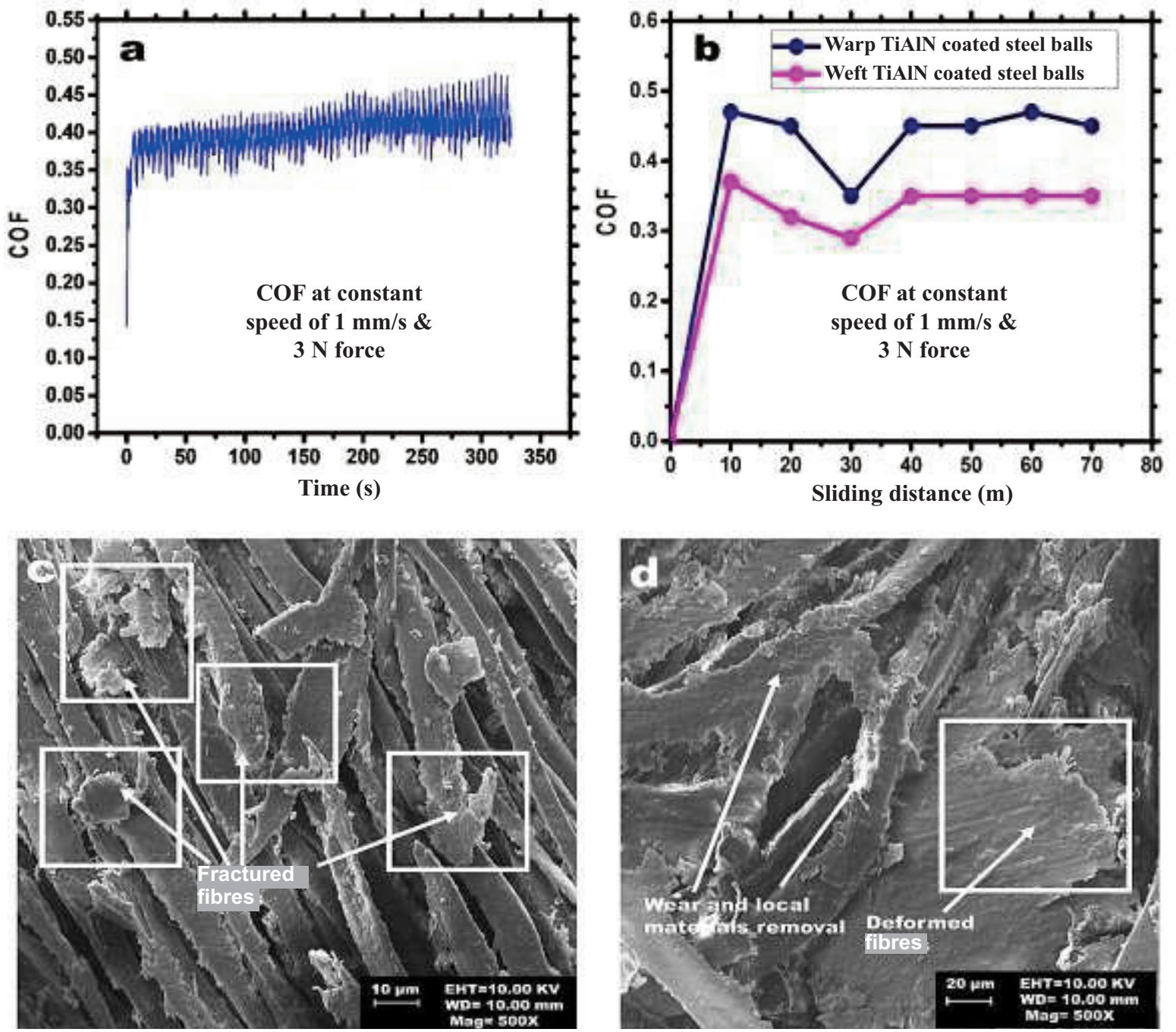

Fig. 6. (a) COF versus time variations, (b) COF versus sliding distance observations, (c) SEM image of weft fibres' fracture, (d) SEM image of warp fibres' fracture. 
techniques. Moreover, the higher is the value of thread setting density, linear density, weight per square meter (GSM) and tensile properties, the better will be the performance and quality of textile products $[33,34]$. Based on literature and experimental results, it can be concluded that the relative sliding COF value between textile waste and metallic components during shredding, cutting and recycling should be greater than 0.25 due to damage, rough and damaged surface of textile fabrics [35]. Higher COF values provide better grip, lower cutting resistance and hence better performance and quality of recycled products.

\section{CONCLUSIONS}

The TiAlN coatings have manifested the creation of better composite surfaces for fabric tribology, they show small surface roughness and high microhardness. The developed coatings were used for COF evaluation between sliding balls and textile fabrics. SEM and CETR tribometers were employed for coatings, fabric surfaces, and COF estimation. The fabric surface was found primarily rough and distorted and the cotton fabric had loose fibres that drifted over the yarn surface in three dimensions. The TiAlN SEM images justified the smooth and homogeneous distribution of coatings. Similar results were confirmed by using optical and mechanical profilometers. The variations in force, speed and wear distance during sliding between the cotton fabric and the coated balls show maximum and minimum COF values from 0.47 to 0.30 in warp and from 0.35 to 0.23 in weft directions, respectively. Optimistically, the COF becomes constant after $40 \mathrm{~m}$ of wear distance. The higher COF values provide better friction and grip between cutting tools and fabric surfaces. The TiAlN coatings can also be used for cutting tools, shredding parts, and textile machinery parts to recycle rough, distorted, and damaged textile waste.

\section{ACKNOWLEDGEMENTS}

This study was financially supported by the project KIK 19019 "Developing of textile waste shredding technology and innovative materials to adding value to textile waste and support the circular economy". The publication costs of this article were covered by the Estonian Academy of Sciences.

\section{REFERENCES}

1. Wang, J., Ma, J., Huang, W., Wang, L., He, H. and Liu, C. The investigation of the structures and tribological properties of FDLC coatings deposited on Ti-6Al-4V alloys. Surf. Coat. Technol., 2017, 316, 22-29.

2. Tian, B., Yue, W., Fu, Z.-Q., Gu, Y., Chengbiao, W. and Liu, J. Microstructure and tribological properties of W-implanted PVD TiN coatings on 316L stainless steel. Vacuum, 2014, 99, 68-75.

3. Steffen, W., Richardson, K., Rockström, J., Cornell, S. E., Fetzer, I., Bennett, E. M. et al. Planetary boundaries: Guiding human development on a changing planet. Science, 2015, 347(6223), 1259855.

4. Ütebay, B., Çelik, P. and Çay, A. Effects of cotton textile waste properties on recycled fibre quality. J. Clean. Prod., 2019, 222, 29-35.

5. Cutting Tools. Dedalus Consulting. New York, NY. https://www.dedalusconsulting.com

6. Han, X., Zheng, J., Hao, J., Shuaituo and Zhang. The microstructure, mechanical and tribological properties of a-C:H films with self-assembled carbon nanohoops. Surf. Coat. Technol., 2017, 311, 27-34.

7. Wang, C. Y., Xie, Y. X., Qin, Z., Lin, H. S., Yuan, Y. H. and Wang, Q. M. Wear and breakage of TiAlN- and TiSiNcoated carbide tools during high-speed milling of hardened steel. Wear, 2015, 336-337, 29-42.

8. Chang, Y.-Y. and Hsiao, C.-Y. High temperature oxidation resistance of multicomponent $\mathrm{Cr}-\mathrm{Ti}-\mathrm{Al}-\mathrm{Si}-\mathrm{N}$ coatings. Surf. Coat. Technol., 2009, 204(6-7), 992-996.

9. Shanmugavelayutham, G., Selvarajan, V., Yugeswaran, S., Vijay, M., Suresh. K., Vijeyakumar, S. et al. Performance study of wear resistance and solid lubricant surface coatings on textile machinery components. Compos. Interfaces, 2012, 19(3-4), 239-249.

10. Merlo, A. M. The contribution of surface engineering to the product performance in the automotive industry. Surf. Coat. Technol., 2003, 174-175, 21-26.

11. Ernst, P. and Barbezat, G. Thermal spray applications in powertrain contribute to the saving of energy and material resources. Surf. Coat. Technol., 2008, 202(18), 4428-4431.

12. Donnet, C. and Erdemir, A. Historical developments and new trends in tribological and solid lubricant coatings. Surf. Coat. Technol., 2004, 180, 76-84.

13. Peng, Z., Miao, H., Qi, L., Yang, S. and Liu, C. Hard and wear-resistant titanium nitride coatings for cemented carbide cutting tools by pulsed high energy density plasma. Acta Mater, 2003, 51(11), 3085-3094.

14. Tian, X., Yan, K., Zhao, J., Cheng, Y. and Zhongbin, W. Thermal and mechanical shock resistances of Si3N4/(W, Ti) $\mathrm{C}$ graded nanocomposite ceramic tool material. Ceram. Int., 2020, 46(2), 2317-2324.

15. Lorenzo-Martin, C., Ajayi, O. O., Erdemir, A., Fenske, G. R. and Wei, R. Effect of microstructure and thickness on the friction and wear behavior of $\mathrm{CrN}$ coatings. Wear, 2013, 302(1-2), 963-971.

16. Luo, Q. Temperature dependent friction and wear of magnetron sputtered coating TiAlN/VN. Wear, 2011, 271(9-10), 2058-2066.

17. Birol, Y. Sliding wear of $\mathrm{CrN}, \mathrm{AlCrN}$ and AlTiN coated AISI H13 hot work tool steels in aluminium extrusion. Tribol. Int., 2013, 57, 101-106.

18. Chu, K., Shum, P. W. and Shen, Y. G. Substrate bias effects on mechanical and tribological properties of substitutional solid solution ( $\mathrm{Ti}, \mathrm{Al}) \mathrm{N}$ films prepared by reactive magnetron sputtering. Mater. Sci. Eng. B, 2006, 131(1-3), 62-71. 
19. Shum, P. W., Tam, W. C., Li, K. Y., Zhou, Z. F. and Shen, Y. G. Mechanical and tribological properties of titaniumaluminium-nitride films deposited by reactive close-field unbalanced magnetron sputtering. Wear, 2004, 257(9-10), 1030-1040.

20. Darden, M. A. and Schwartz, C. J. Investigation of skin tribology and its effects on the tactile attributes of polymer fabrics. Wear, 2009, 267(5-8), 1289-1294.

21. Frącczak, Ł., Matusiak, M. and Zgórniak, P. Investigation of the friction coefficient of Seersucker woven fabrics. Fibres Text. East. Eur., 2019, 27, 3(135), 36-42.

22. Bueno, M. A., Lamy, B., Renner, M. and Viallier-Raynard, P. Tribological investigation of textile fabrics. Wear, 1996, 195(1-2), 192-200.

23. Tang, K.-p. M., Kan, C.-w. and Fan, J.-t. Assessing and predicting the subjective wetness sensation of textiles: subjective and objective evaluation. Text. Res. J., 2014, 85(8), 838-849.

24. Mukhopadhyay, A. and Midha, V. K. The quality and performance of sewn seams. In Joining Textiles. Woodhead Publishing, 2013, 175-207.

25. Hearle, J. W. S., Lomas, B. and Cooke, W. D. Atlas of Fibre Fracture and Damage to Textiles. Woodhead Publishing, 1998.

26. Qi, Z., Sun, P., Zhu, F. P., Wu, Z. T., Liu, B., Wang, Z. C. et al. Relationship between tribological properties and oxidation behavior of $\mathrm{Ti}_{0.34} \mathrm{Al}_{0.66} \mathrm{~N}$ coatings at elevated temperature up to $900{ }^{\circ} \mathrm{C}$. Surf. Coat. Technol., 2013, 231, 267-272.

27. Ramadoss, R., Kumar, N., Pandian, R., Dash, S., Ravindran, T. R., Arivuoli, D. et al. Tribological properties and deformation mechanism of TiAlN coating sliding with various counterbodies. Tribol. Int., 2013, 66, 143-149.

28. Barnes, C. J., Childs, T. H. C., Henson, B. and Southee, C. H. Surface finish and touch - a case study in a new human factors tribology. Wear, 2004, 257(7-8), 740-750.

29. Das, A., Kothari, V. K. and Vandana, N. A study on frictional characteristics of woven fabrics. Autex Res. J., 2005, 5(3), 133-140.

30. Kothari, V. K., Das, A. and Sreedevi, R. Cut resistance of textile fabrics - A theoretical and an experimental approach. Indian J. Fibre Text. Res., 2007, 32, 306-311.

31. Mo, J., Zhu, M. H., Lei, B., Leng, Y. X. and Huang, L. Comparison of tribological behaviours of AlCrN and TiAlN coatings - Deposited by physical vapor deposition. Wear, 2007, 263(7-12), 1423-1429.

32. Zhou, Z., Rainforth, W. M., Luo, Q., Hovsepian, P. Eh., Ojeda, J. J. and Romero-Gonzales, M. E. Wear and friction of TiAlN/VN coatings against $\mathrm{Al}_{2} \mathrm{O}_{3}$ in air at room and elevated temperatures. Acta Mater., 2010, 58(8), 2912-2925.

33. Mahdu, A., Saha, B., Kumar, M. and Singha, K. Fabric assistance effect on woven fabric tensile strength: a brief review. J. Textile Assoc., 2014, 178-186.

34. Cunniff, P. M. An analysis of the system effects in woven fabrics under ballistic impact. Text. Res. J., 1992, 62(9), 495-509.

35. Abrar, H., Podgursky, V., Goliandin, D., Viljus, M., Antonov, M., Bogatov, A. et al. Tribological and mechanical properties investigations of post-consumer cotton textiles, accepted for publication. In Proceedings of the 28th International Baltic Conference "Materials Engineering and Modern Manufacturing 2020". Trans Tech publications, 2020.

\title{
Tekstiilimasinate osade TiAIN-pinnakatete triboloogilised uuringud
}

\author{
Abrar Hussain, Vitali Podgursky, Dmitri Goljandin ja Maksim Antonov
}

Karedad, kahjustatud ja moonutatud tarbimisjärgsed looduslikud ja sünteetilised polümeerid põhjustavad tekstiilimasinate osade kulumist ning kahjustusi. Neid funktsionaalseid probleeme peetakse taaskasutatud toodete kvaliteedi peamiseks takistuseks. Masinaosade ja tööriistade tõhusus on seotud peamiselt nende mehaaniliste ning triboloogiliste omadustega. Selles artiklis on TiAlN-katteid kasutatud nende triboloogilisi omadusi mõjutava hõõrdeteguri (COF) mõõtmiseks. Puuvillakangaste skaneeriva elektronmikroskoobi (SEM) uuringud näitavad, et kanga pinnal tekkisid pinnakahjustused, moonutused ja lahtised kiud. TiAlN-katete skaneeriva elektronmikroskoobi (SEM) morfoloogiad olid enamasti siledad, homogeensed ja ühtlaselt jaotunud. Lisaks kasutati pinnakatte analüüsiks 3D optilist mikroskoopi ja mehaanilist profilomeetrit. Pinnakatte kareduse parameetriteks olid Rmax $(0,30 \mu \mathrm{m}), \operatorname{Rz}(0,26 \mu \mathrm{m}) \mathrm{ja} \operatorname{Rp}(0,17 \mu \mathrm{m})$. Mikrokõvaduse väärtus HV-skaalal oli $35 \mathrm{GPa}$. Antud madalamad kareduse ja kõrgemad mikrokõvaduse väärtused võimaldavad märkimisväärset suutlikkust. Dünaamilised hõõrdeteguri (COF) väärtused olid 0,30-0,47 lõime ja 0,23-0,35 koe suunas. Hõõrdeteguri väärtused on lõime suunas suuremad väiksema niidi tiheduse, kareda pinna ja eelistatud orientatsiooni, juhuslikult orienteeritud kiudude ning lihtsakoelise struktuuri tõttu. Kulumiskatse kestuse pikenemine põhjustas puuvillkanga deformatsiooni. Leiti, et hõõrdetegur ja deformatsioon muutuvad püsivaks pärast $40 \mathrm{~m}$ pikkust kulumist. Hõõrdeteguri väärtuste, püsivate deformatsioonide ja morfoloogiate hinnangute põhjal järeldati, et TiAlN-katteid võiks kasulikult kasutada purustamis-, lõikamis- ning taaskasutusmasinate osade kaitsmiseks. Tulemused võivad parandada ka taaskasutatud tekstiilitoodete kvaliteeti ja tööiga. 